\title{
Novel targeted therapeutics for MEN2
}

\author{
Sara Redaelli', Ivan Plaza-Menacho² and Luca Mologni1 \\ 1School of Medicine and Surgery, University of Milano-Bicocca, Monza, Italy \\ 2Spanish National Cancer Research Center (CNIO), Madrid, Spain \\ Correspondence should be addressed to L Mologni: luca.mologni@unimib.it \\ This paper is part of a thematic review section on 25 Years of RET and MEN2. The guest editors for this section were Lois Mulligan and Frank Weber
}

\begin{abstract}
The rearranged during transfection (RET) proto-oncogene was recognized as the multiple endocrine neoplasia type 2 (MEN2) causing gene in 1993. Since then, much effort has been put into a clear understanding of its oncogenic signaling, its biochemical function and ways to block its aberrant activation in MEN2 and related cancers. Several small molecules have been designed, developed or redirected as RET inhibitors for the treatment of MEN2 and sporadic MTC. However, current drugs are mostly active against several other kinases, as they were not originally developed for RET. This limits efficacy and poses safety issues. Therefore, there is still much to do to improve targeted MEN2 treatments. New, more potent and selective molecules, or combinatorial strategies may lead to more effective therapies in the near future. Here, we review the rationale for RET targeting in MEN2, the use of currently available drugs and novel preclinical and clinical RET inhibitor candidates.
\end{abstract}

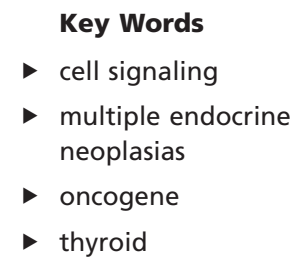

Endocrine-Related Cancer (2018) 25, T53-T68

\section{MEN2: introduction}

Mary (fictitious name) is a beautiful and joyful eighteenyear-old girl who enjoys her life. You do not notice anything wrong with her, if not for her slightly too long and slender fingers and limbs. She has multiple endocrine neoplasia type 2 (MEN2) and a marfanoid appearance. However, in a sense, she is lucky: the cause of her disease had been discovered few years before her birth. Now, she is under treatment with a drug that keeps the disease at bay.

MEN2 is a group of hereditary, autosomal dominant syndromes characterized by the occurrence of various endocrine tumors (Schimke 1984). Three MEN2 clinical subtypes are recognized: MEN2A, MEN2B and familial MTC (FMTC). MEN2A patients develop medullary thyroid carcinoma (MTC), pheochromocytoma and parathyroid hyperplasia or adenoma. In contrast, MEN2B patients do not have parathyroid involvement, but often show a number of additional conditions, such as marfanoid features and mucosal neuromas of the lips and the tongue and gastrointestinal manifestations (Marx 2005, Wells et al. 2013). Moreover, MEN2B is generally more aggressive and occurs earlier in life. FMTC patients only develop MTC; thus, some authors view FMTC as a MEN2A variant without adrenal gland involvement. Clinical management of MEN2 patients includes prophylactic thyroidectomy, periodical biochemical screening for urine catecholamine and epinephrine, as well as serum calcium, calcitonin and parathyroid hormone levels and surgical removal of tumors. The etiology of MEN2 syndrome remained obscure until 1993, when Mulligan and coworkers discovered germline mutations of the RET proto-oncogene in MEN2A patients (Mulligan et al. 1993). RET is a signaling co-receptor for neurotrophic factors (Edery et al. 1997). At that time, it was known to be frequently rearranged in papillary thyroid cancers 
(PTC), but its involvement in MEN2 and MTC was not yet clear (Grieco et al. 1990, Santoro et al. 1990). The paper by Mulligan and colleagues opened a new era for specific treatment of these conditions. MEN2A patients carry cysteine-specific mutations in the extracellular domain of RET, that are involved in conformational stability and kinase activity via intramolecular disulfide bridges. These mutations cause covalent dimerization of RET leading to ligand-independent kinase activation (PlazaMenacho et al. 2006, Mologni 2011, Goodman et al. 2014). Mutations affecting cysteine 634 account for most cases, with $\mathrm{C} 634 \mathrm{~W}$ being the most prevalent MEN2A mutation, although other cysteines from the cysteine-rich domain (CRD) have been described (Ito et al. 1997). In contrast, the vast majority of MEN2B patients carry a M918T mutation in the catalytic domain of RET. Methionine 918 is located near the kinase activation loop: mutation to threonine causes the opening of the activation loop and induces faster autophosphorylation kinetics (PlazaMenacho et al. 2014). FMTC can be caused by both extraand intracellular domains mutations, including cysteine substitutions at the CRD and kinase domain-activating mutations. Of particular interest from a pharmacological standpoint are FMTC mutations at the gatekeeper valine, V804, which render the kinase refractory to inhibition by some inhibitors (Carlomagno et al. 2004, Mologni et al. 2013).

\section{RET signaling in MEN2}

Molecular dissection of disease-driving mechanisms is fundamental for the development of precise therapeutics able to target the disease causative process while sparing normal functions on the organism. Perturbation of RET signaling by a series of oncogenic events, i.e. single germline/somatic point mutation, gene rearrangement, overexpression or transcriptional upregulation, is a common hallmark in several human cancers. The understanding of the mechanism of action associated with these oncogenic RET 'variants' is crucial for the development of more accurate (i.e., targeted) and successful therapeutic strategies to treat patients with RET-positive cancers.

Despite clear genotype-phenotype correlations observed in the cancer syndrome MEN2, the molecular mechanisms linking the different sets of RET mutations with their specific clinical subtypes are far from understood. Work from the last two and a half decades on the genetics and cell signaling of the RET proto-oncogene has described two main mechanisms of action for specific disease-phenotype-associated RET mutations. First, mutations affecting the extracellular cysteine-rich domain (CRD) of RET, associated with MEN2A and FMTC, lead to covalent dimerization and constitutive activation of the receptor (Takahashi et al. 1999). The recent elucidation of the structural architecture of RET extracellular domain in complex with GDNF-GFR $\alpha 1$ showed a composite ligandbinding site, with RET wrapping around the co-receptor/ ligand complex (Goodman et al. 2007). A GFR $\alpha 1$-binding hotspot contacts the RET cadherin-like domains, while the CRD contacts both ligand components and makes membrane-proximal homotypic interactions, leading to receptor homodimerization and activation. These CRDmediated interactions suggest models both for ligandinduced RET activation and for ligand-independent oncogenic dysregulation by MEN2 cysteine mutations (Goodman et al. 2007). Second, mutations affecting the intracellular domain of RET, usually associated with FMTC and always with the MEN2B phenotype, transform the receptor into a monomeric ligand-independent oncoprotein (Santoro et al. 1995). RET MEN2B variants, in particular RET M918T, show not only an altered catalytic activity but also an altered substrate specificity because they preferentially phosphorylate substrates that, contrary to wild-type RET, are usually preferred by cytoplasmic tyrosine kinases such us FAK (Murakami et al. 1999) and SRC (Kato et al. 2002, Encinas et al. 2004, PlazaMenacho et al. 2011). The transcription factor STAT3 is one such example (Yuan et al. 2004). In addition, RET-MEN2B mutants seem to lack dependency on activation loop Y905 for both cells transformation and signaling (Iwashita et al. 1996, 1999). One plausible explanation about the molecular basis of the disease spectrum is that a different pattern of receptor autophosphorylation displayed by specific RET mutants connects a different set of phospho-tyrosine-mediated downstream signaling pathways and transcriptional programs with specific clinical phenotypes. Recent biochemical, biophysical and structural evaluation of RET M918T and V804M mutants (both targeting the catalytic domain of RET) revealed increased kinetics of autophosphorylation and a more extended activation loop conformation, giving rise to a better intermolecular substrate compared to RET WT (Plaza-Menacho et al. 2014). These data have important implications due to the perturbation of the temporal assembly and specificity of RET signaling complexes. Another interesting observation is that oncogenic RET seems to be heavily internalized and prolonged treatment with specific tyrosine kinase inhibitors (e.g. sorafenib) induced lysosomal degradation 
(Plaza-Menacho et al. 2007). Interestingly, degradation promoted by tyrosine kinase inhibitor (TKI) was apparently higher for RET C634R (MEN2A) than RET M918T (MEN2B). However, blocking HSP90 activity by 17-AAG induced an equally potent degradation of wildtype RET and MEN2-associated RET mutants (Alfano et al. 2010). Altogether these studies highlight the complexity of RET (oncogenic) signaling, in a way that localization of the receptor in specific subcellular compartments, maturation status and the interaction with intracellular and extracellular components are important elements to understand RET function and oncogenic deregulation.

The rationale of a different temporal pattern of receptor activation with specific clinical phenotypes (PlazaMenacho et al. 2006) has been supported by several studies. In cell-based experiments, RET M918T (MEN2B) triggers elevated levels of PI3K activity (Murakami et al. 1999) and Jun N-terminal kinase activity JNK (Murakami et al. 2002) compared with RET C634R. In addition, RET M918T switches the specificity of the RET tyrosine kinase toward alternatives substrates that interact with Crk and Nck (Bocciardi et al. 1997). The same applies to the interaction with other SH2- or PTB-containing docking/adaptor proteins. For example, RET M918T (MEN2B) showed both enhanced phosphorylation of Y1062 and association with SHC, compared with RET C634R (MEN2A) mutants, resulting in the higher activation of the RAS/ERK1/2 and the PI3K/AKT signaling pathways (Salvatore et al. 2001). Liu and colleagues showed that RET-MEN2B mutants lack phosphorylation at Y1096, directly leading to a decrease in binding of GRB2 to RET, compared with wild-type RET (Liu et al. 1996). Transactivation of STAT3 by RET C634R (MEN2A) is required for cellular transformation in a process that is independent of non-receptor tyrosine kinases JAKs and SRC (Schuringa et al. 2001). On the contrary, activating point mutations targeting the kinase domain, such as RET Y791F and RET S891A (FMTC) implicate JAKs and SRC kinases in the constitutive activation of STAT3 (Plaza Menacho et al. 2005). In another study, oncogenic RET M918T (MEN2B) was shown to interact with and activated STAT3 more strongly than RET C634R (MEN2A) (Yuan et al. 2004). In the same line, oncogenic RET enhanced in cells the phosphorylation levels of FAK activation loop Y576/577 phosphorylation compared to wild-type RET, and kinase domain mutants (RET M918TMEN2B and RET V804M, a FMTC-associated drug-resistant mutant) induced a more robust phosphorylation than mutants targeting the extracellular domain (e.g., RET C634R, MEN2A). Interestingly, this pattern was mirrored by levels of SRC Y416 kinase activation promoted by RET, indicating a close relationship between levels of RET, FAK, SRC and STAT3 activation (Plaza-Menacho et al. 2011).

Taken all together, these studies indicate that specific sets of signaling pathways are connected with specific sets of MEN2-associated RET mutations. A better understanding of the molecular mechanisms underlying this cancer syndrome ultimately will be necessary to design new therapeutic strategies to treat this disease. Combinatorial therapies targeting RET and other important (diseasespecific) downstream effectors may be a real alternative to mono-therapies based on TKIs targeting (oncogenic) RET catalytic activity (see below).

\section{Targeted treatments for MEN2/MTC}

\section{Approved drugs}

The spectacular success of imatinib in chronic myeloid leukemia (CML) patients in early 2000s (Kantarjian et al. 2002) indicated that targeted treatment may change a disease history in rationally selected patients. Belonging to the same protein class as the imatinib target ABL1, RET was the next kid on the block. A list of completed and ongoing clinical trials investigating the efficacy of RET inhibitors in familial thyroid cancer is shown in Table 1.

Vandetanib (Caprelsa, ZD6474, Genzyme Corp), an orally available kinase inhibitor active against VEGFR2 and EGFR, was later found to be also a potent RET inhibitor (Carlomagno et al. 2002, Wedge et al. 2002, Vidal et al. 2005). The efficacy and safety of vandetanib in patients with MTC were first evaluated in two phase II studies (Robinson et al. 2010, Wells et al. 2010). In the trial conducted by Robinson and colleagues, vandetanib administered $100 \mathrm{mg} /$ daily which resulted in a partial response (PR) in $16 \%$ of the patients and in stable disease (SD) for at least 24 weeks in $53 \%$ of the treated cases. Wells and colleagues described the use of $300 \mathrm{mg} /$ daily as able to induce a PR in $20 \%$ of patients and a SD in $53 \%$, with a median progression-free survival (PFS) of 27.9 months. A large multicenter, randomized placebocontrolled crossover phase III study was conducted in a cohort of 331 patients with hereditary and sporadic forms of MTC (ZETA trial, Wells et al. 2012). The patients were randomly divided $2: 1$ between vandetanib $(300 \mathrm{mg} /$ daily, $n=231)$ or placebo $(n=100)$ arms. The predicted median PFS for the vandetanib arm was 30.5 months, significantly higher than the 19.3 months observed for placebo. A PR was observed in $45 \%$ patients with a predicted median duration of 22 months, while $42 \%$ had SD, yielding a disease control rate of $87 \%$. The analysis showed evidence 
Table 1 Clinical trials investigating RET inhibitors in medullary thyroid cancer patients.

\begin{tabular}{|c|c|c|c|c|c|}
\hline Phase & Drug & Dose\# & Condition & Outcome* & Reference/ID \\
\hline II & Vandetanib & 100 mg/day & FMTC & $16 \%$ PR, $53 \%$ SD & (39) \\
\hline II & Vandetanib & 300 mg/day & FMTC & $20 \%$ PR, $53 \%$ SD & $(40)$ \\
\hline III & Vandetanib & 300 mg/day & MTC & $45 \% \mathrm{PR}, 42 \% \mathrm{SD}$ & (41) \\
\hline $\mathrm{I} / \mathrm{II}$ & Vandetanib & $150 \mathrm{mg} / \mathrm{m}^{2} /$ day & MEN2B & $44 \%$ ORR & $(42)$ \\
\hline I & Cabozantinib & Dose finding & MTC & $29 \%$ PR, $41 \%$ SD & $(45)$ \\
\hline III & Cabozantinib & 140 mg/day & MTC & $28 \%$ PR & $(46)$ \\
\hline II & Sorafenib & $400 \mathrm{mg}$ bid & MTC & $6 \% \mathrm{PR}, 88 \% \mathrm{SD}$ & $(51)$ \\
\hline II & Sorafenib & $400 \mathrm{mg}$ bid & MTC/DTC & $25 \% \mathrm{PR}, 70 \% \mathrm{SD}$ & $(52)$ \\
\hline II & Lenvatinib & 24 mg/day & MTC & $36 \%$ PR & (57) \\
\hline II & Sunitinib & $37.5 \mathrm{mg} / \mathrm{day}$ & MTC/DTC & $50 \%$ PR & $(61)$ \\
\hline II & Sunitinib & $50 \mathrm{mg} / \mathrm{day}$ & MTC/DTC/ATC & $38 \%$ PR, 50\% SD & $(62)$ \\
\hline II & Motesanib & 125 mg/day & MTC & $2 \% \mathrm{PR}, 81 \% \mathrm{SD}$ & $(74)$ \\
\hline II & Fostamatinib & $200 \mathrm{mg}$ bid & Multi-histology & $50 \%$ SD & (79) \\
\hline $\mathrm{I} / \mathrm{II}$ & Alectinib & Bid, dose finding & RET-mutated thyroid cancer & n.d. & NCT03131206 \\
\hline I & LOXO-292 & Dose finding & $\mathrm{MTC}$ & n.d. & NCT03157128 \\
\hline II & Ponatinib & $30 \mathrm{mg} / \mathrm{day}$ & $\begin{array}{l}\text { MTC, previously treated } \\
\text { with vandetanib or } \\
\text { cabozantinib }\end{array}$ & $\begin{array}{l}100 \% \text { PD halted } \\
\text { for toxicity }\end{array}$ & NCT01838642 \\
\hline II & Ponatinib & n.a. & RET-mutated cancer & n.d. & NCT02272998 \\
\hline II & Apatinib & $500 \mathrm{mg} / \mathrm{day}$ & Thyroid cancer & n.d. & NCT03199677 \\
\hline II & Nintedanib & $200 \mathrm{mg}$ bid & MTC/DTC & n.d. & NCT01788982 \\
\hline I & Dovitinib + paclitaxel & $200 \mathrm{mg} / \mathrm{day}$ & Multi-histology & $\begin{array}{l}100 \% \text { SD (RETmut } \\
\text { non-MTC) }\end{array}$ & $(94)$ \\
\hline II & Pazopanib & 800 mg/day & MTC & $14 \%$ PR & $(98)$ \\
\hline $\mathrm{I}-\mathrm{Ib}$ & RXDX-105 & 20-350 mg/day & $\begin{array}{l}\text { BRAF- or RET-mutated } \\
\text { cancer }\end{array}$ & $1 \mathrm{PR}$ & NCT01877811; (99) \\
\hline I & BLU-667 & Dose finding & $\begin{array}{l}\text { MTC/other RET-mutated } \\
\text { cancer }\end{array}$ & n.d. & NCT03037385 \\
\hline I & GSK3352589 & 1-100 mg/day & Healthy subjects & n.d. & NCT03154086 \\
\hline I & GSK3179106 & $10-200$ mg/day & Healthy subjects & n.d. & NCT02798991 \\
\hline I & GSK3179106 & 5-100 mg/day & Healthy subjects & n.d. & NCT02727283 \\
\hline $\mathrm{I} / \mathrm{II}$ & Vandetanib + bortezomib & Up to $300 \mathrm{mg}$ qd & MTC & $29 \%$ PR & NCT00923247 \\
\hline Ib & Semaxanib + paclitaxel & $\begin{array}{l}110 \mathrm{mg} / \mathrm{m}^{2} \text { on days } 1,15 \\
18,22 \text { and } 25\end{array}$ & Head and neck & $100 \%$ SD & $(141)$ \\
\hline I & Vandetanib + everolimus & Starting $100 \mathrm{mg} /$ day & Advanced cancers & n.d. & NCT01582191 \\
\hline
\end{tabular}

\#In combination studies, the data refer to the RET inhibitor; * refers to the MTC population only, when the study involved other cancer types (unless specified).

ATC, anaplastic thyroid carcinoma; bid, bis in die (twice daily); DTC, differentiated thyroid carcinoma; MTC, medullary thyroid carcinoma; ORR, overall response rate; $P D$, progressive disease; $P R$, partial response; SD, stable disease.

that RET mutation-positive patients had higher benefit than RET-negative ones, although the trend did not reach statistical significance due to the limited number of patients in the latter group. Adverse events (AEs) were observed in more than $30 \%$ of patients and included diarrhea, nausea, rash and hypertension. About half (49\%) of the patients had a vandetanib-related increase of TSH levels and 8\% of cases developed QTc prolongation. Five patients died because of serious side effects. Based on these results, the FDA (in 2011) and the EMA (in 2012) approved the use of vandetanib for the treatment of symptomatic or progressive medullary thyroid cancer in patients with unresectable locally advanced or metastatic disease. More recently, a phase I/II study aimed to assess the drug's safety, tolerance, pharmacokinetic as well as the antitumor activity in a cohort of 10 adolescents and 6 children affected by MEN2B-associated MTC (Fox et al. 2013). All the patients but one expressed the M918T RET mutation. The tumor size decreased in all the 15 patients carrying the mutation. The overall objective response rate was $44 \%$ (7/15 patients; 95\% confidence interval (CI): $21-73 \%$ ) with a decrease in calcitonin level of $59 \%$ after one cycle of therapy. However, three children experienced progression after an initial PR.

An alternative to vandetanib is currently represented by cabozantinib (Cometriq, XL-184, Exelixis Inc), a potent inhibitor of MET, VEGFR2/KDR, RET, as well as other receptor tyrosine kinases, such as KIT, AXL and FLT3. In in vitro biochemical assays, cabozantinib displays inhibitory activity against both wild-type and mutated 
M918T and Y791F RET forms associated with MTC (Yakes et al. 2011, Bentzien et al. 2013). Cabozantinib received FDA approval in 2012 and EMA approval in 2014 for the treatment of patients with progressive metastatic MTC. The activity of cabozantinib was firstly assessed in a phase I study on 87 patients with different solid tumors, including 37 MTC patients (Kurzrock et al. 2010). In the MTC subgroup 29\% of cases achieved a PR and $41 \%$ had a SD for at least 6 months. The subsequent multicenter, randomized, placebo-controlled phase III EXAM study (Elisei et al. 2012) involved 330 patients with histologically confirmed unresectable, locally advanced or metastatic MTC that were randomly assigned 2:1 either to cabozantinib ( $140 \mathrm{mg} /$ daily) or to placebo. Forty-eight percent patients harbored RET mutations. The PFS observed for the cabozantinib arm was significantly longer than placebo (11 vs 4 months, hazard ratio (HR) 0.28). PR was achieved in $28 \%$ of patients with a median duration of response of 14.7 months, while the median overall survival (OS) did not significantly differ in the two arms: 26.6 months under cabozantinib and 21.1 in the placebo group $(P=0.24)$. In the subgroups harboring RET mutation, a PR was observed in $34 \%$ of cases, PFS was 13.9 months and the OS was 44.3 months (vs 18.9 months in the placebo arm, $P=0.025)$. The most frequent AEs of grade 3 and 4 were diarrhea, hand-foot syndrome, fatigue and hypertension.

\section{Investigational drugs}

Several small molecules have been designed, developed or repurposed as RET kinase inhibitors during the past decade (reviewed in Phay \& Shah 2010, Mologni 2011, Borrello et al. 2013, Mologni et al. 2017a,b). Some have already been approved for non-MEN2 thyroid cancer and are under investigation for MEN2, others are in advanced clinical development or have been clinically tested in a limited number of patients.

Sorafenib (Nexavar, Bay 43-9006, Bayer Healthcare Pharmaceuticals Inc) is an orally available VEGFR1-3, RET, BRAF and PDGFR inhibitor. Its use in differentiated thyroid carcinoma (DTC) has been approved by the FDA and the EMA in 2013 and 2014, respectively (Brose et al. 2014). Sorafenib activity in MTC was assessed in two prospective phase II studies (Lam et al. 2010, Ahmed et al. 2011). Lam and colleagues enrolled 21 MTC patients observing a PR in 6\% of cases and SD in 88\%. The PFS was 17.9 months. Similarly, Ahmed and colleagues studied a cohort of 15 MTC: $25 \%$ of cases achieved a PR, and the authors reported $100 \%$ OS at 12 months. Adverse events observed upon treatment with sorafenib in MTC patients, as well as in other thyroid cancer types include hand-foot syndrome, diarrhea, skin rash and fatigue. Larger cohorts will have to be evaluated before drawing conclusions on the efficacy of sorafenib in these patients.

Lenvatinib (Lenvima, E7080, Eisai Co Ltd) is an orally available multi-targeted TKI with reported activity against VEGFR 1-3, FGFR 1-4, PDGFR alpha, RET and KIT (Matsui et al. 2008, Bruheim et al. 2011, Wiegering et al. 2014). Lenvatinib has been approved by the EMA and the FDA for the treatment of patients with progressive radioiodine-refractory DTC recurrent or metastatic (Nair et al. 2015). The use of lenvatinib in MTC has been explored by Schlumberger and colleagues in a multicenter phase II study involving 59 patients treated with $24 \mathrm{mg}$ /day in 28-day cycles (Schlumberger et al. 2016). The primary endpoint of the study was ORR, which was 36\% (all PRs). Patients with or without prior VEGFR-targeted treatment responded similarly (35\% vs 36\% RR, respectively). Median PFS was 9 months and the achieved response was not affected by the RET mutational status.

Among the most advanced investigational compounds, sunitinib (Sutent, SU11248; Pfizer Ltd) has completed phase I and II trials in thyroid cancer (Dawson et al. 2008, Carr et al. 2010, Atallah et al. 2016, Bikas et al. 2016, Ravaud et al. 2017) and is currently undergoing specific evaluation in RET fusion-positive tumors (NCT02450123). Sunitinib was part of a large indolinone compound collection at SUGEN Inc (later acquired by Pfizer), which was initially developed to block angiogenic kinases belonging to the split tyrosine kinase domain family (VEGFR, FGFR, PDGFR) (Sun et al. 1998, $1999,2000)$. Later, a few closely related compounds from this series were shown to inhibit RET at submicromolar concentrations in vitro and in vivo (Kim et al. 2006, Mologni et al. 2006, Chow \& Eckhardt 2007, Jeong et al. 2011). Among these, SU11248 showed the best pharmacologic properties and progressed into clinical trials. Thus, although the published anti-RET preclinical data are scarce, and despite the broad multikinase activity of sunitinib, its safety profile is already well established from previous trials for other targets (it is approved for renal-cell carcinoma and imatinib-refractory GIST). This prompted clinical investigation in thyroid cancer patients. Overall, Sutent achieved 20-40\% objective responses and $70-80 \%$ disease control rate (including SD) in the thyroid cancer patients' population, which is in line with the currently approved drugs. Sunitinib was generally well tolerated in these patients, with mostly grade 1 or 2 treatment-related adverse events. The most frequent 
toxicities observed in the different studies were fatigue, hand-foot syndrome, leukopenia and diarrhea, in some cases reaching grade $3-4$ severity and leading to treatment discontinuation (about 10\%) or dose reduction from the recommended 37.5 to $25 \mathrm{mg} /$ die. One report described cardiac events in $14 \%$ of patients, half of whom had a severe episode (Ravaud et al. 2017). None of the other studies in thyroid cancer patients reported cardiovascular events; however, sunitinib had been watched for cardiovascular risk in patients with renal-cell carcinoma and gastrointestinal stromal tumors (Chu et al. 2007). A KIF5B-RET-positive non-small-cell lung cancer (NSCLC) case was reported with rapid response to sunitinib and clinical improvement after three days of treatment, in a heavily compromised patient (Wu et al. 2015). However, treatment was discontinued after 10 weeks for toxicity. Unfortunately, significant toxic effects seem relatively common among patients treated with sunitinib, which likely reflects its lack of selectivity. This may limit its clinical efficacy.

Motesanib (AMG-706, Amgen/Takeda) was originally developed by Amgen as an anti-angiogenic drug targeting VEGFR and c-Kit (Polverino et al. 2006). Activity was also noted in vitro against RET kinase in the nanomolar range, although with 1-log reduced potency compared to the primary targets. Thus, RET was a clinically interesting off target for motesanib. The compound was highly selective vs a number of other kinases. This may be due to its ability to make contact with small gatekeeper residues, which RET (V804), VEGFR (V916) and c-Kit (T670) have in common. On the other hand, this is a vulnerability, as motesanib is totally inactive against gatekeeper mutants, such as RET V804M (Mologni et al. 2013). In further preclinical studies, motesanib inhibited wildtype but not mutant RET C634W and M918T phosphorylation in cells. Consequently, proliferation of cells driven by mutant RET was not affected. However, in animal models, motesanib showed antitumor activity against xenografts carrying a M918T mutant RET (Coxon et al. 2012). This apparent contradiction is probably explained by antiangiogenic effects of the drug. Clinical development of motesanib was later taken up by Takeda. In phase II studies, the drug showed modest activity in MTC (2\% PR, $81 \% \mathrm{SD})$ as well as in DTC (14\% PR, 67\% SD) patients (Sherman et al. 2008, Schlumberger et al. 2009). Moreover, pharmacokinetic analyses indicated that motesanib trough concentrations were lower in MTC compared to DTC patients. The vast majority of patients (88\%) experienced AEs, with a significant proportion (38\%) of grade 3 AEs (Schlumberger et al. 2009). Currently, motesanib is mostly undergoing clinical evaluation as a VEGFR, PDGFR and c-Kit inhibitor (Raghav \& Blumenschein 2011).

Fostamatinib is a multikinase inhibitor prodrug currently investigated as a SYK inhibitor (Bajpai 2009). Also in this case, the compound was inadvertently found to block RET kinase activity (Clemens et al. 2009). A recent multi-histology trial evaluated four thyroid cancer patients (papillary and follicular type), two of whom achieved SD as their best response (Park et al. 2013). In addition, one of the two patients with pheochromocytoma had durable SD. Although no MTC patient was enrolled, these data may encourage investigation of fostamatinib in MEN2 patients.

Alectinib (Alecensa, CH5424802, Roche/Chugai) is an anaplastic lymphoma kinase (ALK) inhibitor, approved for the treatment of advanced NSCLC refractory to crizotinib (Gadgeel et al. 2014). It was subsequently shown to be an effective RET inhibitor in vitro and in vivo (Kodama et al. 2014). Although alectinib is not quite as potent against RET as it is against ALK, the compound is active on most RET mutants tested and shows very good selectivity for RET vs VEGFR, which may be a competitive advantage over competing drugs. Alectinib will soon be tested in RET-rearranged NSCLC and RET-mutated thyroid cancer patients, in a non-randomized phase I/II study at Dana-Farber Cancer Institute (NCT03131206). A recent study reported objective responses in two of four RETrearranged NSCLC patients (Lin et al. 2016a,b). From a clinical standpoint, alectinib has the advantage of already being well characterized. Whether it will show the same spectacular efficacy in RET-positive tumors as observed in ALK-driven disease remains to be ascertained.

Loxo Oncology recently developed a selective RET inhibitor named LOXO-292 with $>100 \times$ selectivity vs KDR/VEGFR2, which compares favorably with cabozantinib and vandetanib on both wild-type and mutant RET (Brandhuber et al. 2016). The molecule shows good oral bioavailability and pharmacokinetics (PK) in animals, as well as high efficacy in RET-dependent tumor models, including xenografts and patient-derived tumor grafts. A multicenter phase I trial in patients with advanced RET fusion-positive NSCLC and MTC is currently recruiting participants (NCT03157128), to define the maximum tolerated dose (MTD).

Ponatinib (Iclusig, AP-24534, Ariad Pharmaceuticals) was developed to circumvent the highly intractable ABL gatekeeper mutant T315I in Philadelphia-positive chronic myeloid leukemia (Zhou et al. 2011, Cortes et al. 2012). It has been approved for the treatment of adult patients with T315I-positive CML and ALL or patients that have failed 
all other TKIs. Most like the V804M/L mutants of RET, substitution of a bulky isoleucine for wild-type threonine in $\mathrm{ABL}$ kinase renders the drug-binding site unfit to accommodate imatinib as well as second-generation ABL inhibitors (Quintas-Cardama \& Cortes 2008). Through an innovative design, ponatinib was specifically made to overcome the steric impediment provided by the mutant residue, thus making this drug highly active against gatekeeper mutants. Indeed, when ponatinib was shown to potently inhibit RET (De Falco et al. 2013, Mologni et al. 2013), V804M/L mutants were shown to be effectively blocked. At the time of writing this manuscript, a phase II trial in advanced MTC previously treated with vandetanib and cabozantinib has been terminated prematurely (NCT01838642), and a new study was announced to open soon. Only 2 patients could be evaluated in the closed trial (both RET mutation positive), with no objective response (best response: PD). Other phase II, openlabel trials in advanced NSCLC with RET translocations are currently recruiting patients (NCT01813734 and NCT01935336). Primary outcome will be overall response rate at 2 and 5 years, respectively. A new basket trial is recruiting patients with any refractory metastatic tumor carrying alterations in ponatinib targets, including RET (NCT02272998). As ponatinib is affected by significant systemic toxicity, which led to early termination of the first trial, its use may be confined to second or third lines of TKI therapy. Alternatively, dose reduction might be explored (Pinilla-Ibarz et al. 2013).

Apatinib is a potent VEGFR-2 inhibitor, which also targets PDGFR- $\beta$, c-Src, c-Kit and RET (Scott et al. 2015). Recently, it was shown to block invasion by RET fusionpositive lung cancer cells in vitro (Lin et al. 2016a,b). Since apatinib was already in advanced clinical phases of development (Li et al. 2016) as an anti-angiogenic drug, it is now under evaluation in metastatic refractory thyroid cancer, including MTC (NCT03199677) as well as in RETpositive NSCLC (NCT02540824).

Nintedanib (Vargatef, Ofev, BIBF 1120, Boehringer Ingelheim) is an anti-angiogenic multikinase inhibitor targeting VEGFRs, PDGFRs and FGFRs (Capdevila et al. 2014) used to treat idiopathic pulmonary fibrosis and lung cancer. In a recent retrospective analysis, the drug was reported to have achieved one complete response (CR) and one SD in two RET-rearranged NSCLC patients (Gautschi et al. 2017). Interestingly, according to the same study, ponatinib obtained only stabilization in two treated patients, while alectinib $(n=2)$ failed. However, numbers are too small to draw any conclusions. Cabozantinib, vandetanib and sunitinib, for which at least 10 patients were evaluable, achieved 37, 18 and 22\% overall responses, respectively (Gautschi et al. 2017), in line with observations in thyroid cancer. No data are available for the use of nintedanib in MEN2 or MTC, yet. However, a new phase II study is ongoing in MTC or DTC patients progressing after first-line therapy (NCT01788982).

Dovitinib (TKI258, CHIR258, Novartis) is another multi-targeted angiokinase inhibitor with anti-RET activity. It was investigated in a series of patients with various cancers (not MTC) and found to have sustained antitumor activity in two patients carrying a RETG691s germline variant (Quintela-Fandino et al. 2014). Interestingly, the same variant had previously been found in early-onset MEN2A patients and considered as a genetic modifier, cooperating with known oncogenic mutations to confer high penetrance an activating, oncogenic mutation (Robledo et al. 2003).

Pazopanib (Votrient, GW786034B, GlaxoSmithKline) is a VEGFR1/2/3, PDGFR $\alpha / \beta$, and $c$-Kit inhibitor used for the treatment of renal-cell carcinoma (Sonpavde \& Hutson 2007). It was tested in thyroid cancer patients on the basis of its anti-angiogenic properties, first in DTC (Bible et al. 2010) then in MTC (Bible et al. 2014). While in DTC patients the authors recorded $49 \%$ confirmed PRs, the results in MTC were less encouraging, with only 5/35 (14\%) responding patients. One-third of patients had severe adverse events requiring treatment or dose reduction.

Ignyta Inc is currently evaluating RXDX-105 (formerly CEP-32496) in a phase I clinical trial (NCT01877811) in patients with advanced solid tumors with RET or BRAF mutations or rearrangements (Patel et al. 2016). Although the trial is mostly intended for lung cancer patients, thyroid cancer patients are eligible to be enrolled as well. The compound was actually described as a poorly selective BRAF inhibitor, with potent off-target activity against RET and other kinases (James et al. 2012). Recently, its anti-RET activity was characterized in more detail in vitro and in vivo (Li et al. 2017). The same paper also reports a rapid PR in a NSCLC patient within the ongoing NCT01877811 trial. However, dose reduction was necessary due to toxicity. Indeed, broad inhibitory activity across the kinome of this compound may limit its efficacy in patients.

\section{Next generation of RET targeted drugs}

A new wave of RET-specific compounds is coming up in the next few years. By looking at recently filed patent applications, we get the feeling that the RET inhibitor field is about to burst. Likely, the new interest in RET 
kinase inhibition has been fostered by the discovery of driver RET mutations in NSCLC and colorectal carcinoma. Although representing a minority of total lung and colon cancer patients ( $2 \%$ and $0.2 \%$, respectively), RET fusion-positive cases are still a numerically important population of individuals (estimated 50,000 new cases per year worldwide), which adds up to the number of RETpositive thyroid cancer patients (about 100,000 per year). Moreover, the dismal prognosis of lung and colon cancers make new targeted treatments very attractive. In contrast, the great majority of thyroid cancers (papillary and follicular types) are characterized by high cure rates, while MTC is a rare disease. With cancer genome sequencing approaching routine use, it is probable that more RETpositive cancer types will be detected in the near future. Hence, RET has entered the stage of 'interesting' molecular targets in oncology. This has spurred a race toward RETspecific drug design programs, from which MEN2 patients will definitely benefit. Here we give a brief overview of forthcoming compounds, as of fall 2017.

Among new anti-RET drugs, BLU-667 of Blueprint Medicines has just started clinical phase I trial in 2017 (NCT03037385). It is claimed to be a potent and selective inhibitor of RET mutations and fusions, including drugresistant mutants. The candidate was selected from a series of pyridinyl-pyrimidine derivatives, some of which showed low nanomolar activity against the gatekeeper V804L mutant in preclinical in vitro studies (Fleming et al. 2016, Rahal et al. 2016, 2017). The trial will evaluate safety and tolerability of BLU-667 in patients with RET-positive NSCLC and MTC.

GlaxoSmithKline developed two series of compounds specifically designed to inhibit RET kinase in the nanomolar range (Eidam et al. 2014, Cheung et al. 2016). Their clinical candidates (GSK3352589 and GSK3179106) have recently started phase I, first-in-human, dose escalating controlled studies to evaluate the safety, tolerability and pharmacokinetics in normal healthy volunteers (NCT03154086, NCT02798991 and NCT02727283). Although GSK seems to be developing these compounds for the treatment of irritable bowel syndrome (IBS), they may be as well effective for MEN2 and other RET-driven cancers (Abdel-Magid 2015).

Another interesting family of potential RET inhibitors is represented by quinazoline compounds described by Cancer Research Technology (Goldberg et al. 2015, Newton et al. 2016). Structurally related to vandetanib, these compounds are shown to possess striking selectivity ( $>100 x$ ) over VEGFR2/KDR kinase, which is a very common co-target of several RET inhibitors, whose inadvertent inhibition may potentially cause unwanted side effects and confounding anti-angiogenic activity. Therefore, these molecules may have improved therapeutic index compared to current drugs. The key to increased selectivity compared to vandetanib was a change in substituents around the phenyl ring, which also led to improved metabolic and pharmacokinetic features (Newton et al. 2016). This family was further elaborated in a more recent work, where the authors identified compounds with improved cellular selectivity (Jordan et al. 2016).

Similarly, a very recent patent filed by Array Biopharma claims potent nanomolar RET inhibitors with great selectivity (>30x) vs KDR kinase (Andrews et al. 2017). The inventors also propose the use of combinations including their lead compounds and at least one additional agent, to be chosen among known effective drugs for the treatment of cancer and IBS.

Nerviano Medical Sciences (NMS) has launched an ambitious program for the discovery of RET-selective inhibitors (Angiolini et al. 2014, Menichincheri et al. 2014). Two families of compounds were developed following a common concept of gatekeeper by-pass, shared with ponatinib (see above). In a first series, a triple bond linkage extends from a purine-based core scaffold buried in the active site through binding to the hinge region, bypassing the narrow space around a bulky gatekeeper such as V804M/L mutants of RET. Another recent patent filed by NMS describes compounds with low nanomolar activity and remarkable selectivity for RET+ cells in vitro. Again, the compounds are built by a similar design, with an extended linker joining two parts of the molecule, which are likely to fit nicely into the ATP pocket of the kinase even in the presence of large residues at the 804 position. The best compounds from this series are claimed to possess picomolar activity against MTC cells and are currently under preclinical development, with promising activity in RET-driven animal models (Ardini et al. 2017).

Dar and colleagues (University of California/Mount Sinai School of Medicine) recently described the discovery of potent RET inhibitors showing a high therapeutic window (Dar et al. 2012). Instead of using a classical biochemical screening based on the kinase activity, the authors exploited a Drosophila in vivo MEN2B model coupled with genetic and chemical profiling, toward a high-throughput simultaneous readout of target (RET) and anti-target inhibition. This strategy allowed the identification of hit compounds (AD80 and AD81) with the desired activity and devoid of unwanted toxicity. The findings translated into improved in vivo efficacy and 
tolerability in a mouse xenograft model. Whether this will also hold in humans remains to be demonstrated.

NVP-AST487 is a Flt-3, VEGFR, PDGFR, c-Kit and c-Abl inhibitor with nanomolar activity against RET C634Wtransformed NIH3T3 xenografts (Akeno-Stuart et al. 2007) and in MEN2-derived human cell lines (Gild et al. 2013). It has recently been used to target GDNF-stimulated wildtype RET receptor in MCF7 breast cancer cells, where a role for RET activation in resistance to aromatase inhibitors has been demonstrated (Andreucci et al. 2016).

Pz-1 is a very potent compound described by Synactix Pharmaceuticals (Frett et al. 2015), which was able to completely suppress RET-driven tumor growth in mice at $1 \mathrm{mg} / \mathrm{kg}$. However, the compound also greatly reduced Ras-induced tumors, which raises doubts on its selectivity and therapeutic applicability. Also, strong VEGFR2 inhibition, as said, may help antitumor activity or cause adverse effects.

To conclude this section, it is worth mentioning that several academic groups, including our lab, have published interesting early phase medicinal chemistry papers describing the discovery of novel RET inhibitors with promising in vitro data, in the past three years. Often, efforts were focused on activity against the gatekeeper mutants (Dunna etal. 2015, Ferreira et al. 2015, Moccia et al. 2015, Han et al. 2016, Song et al. 2016, Yoon et al. 2016, 2017, Mologni et al. 2017a,b, Wang et al. 2017). Finally, in a completely different approach, Kumarasamy and Sun described the selective block of RET transcription by a G-quadruplex-stabilizing agent (Kumarasamy \& Sun 2017). By hitting the promoter of RET gene, this strategy would result in suppression of all mutants, but it would not be useful for RET fusions. Similarly, antibody-based approaches such as one described by Takeda (Arai et al. 2007) would hit RET mutants expressed on the cell surface, but not fusion oncogenes, that are localized within the cytoplasm. More universal targeting approaches are possible, including antisense, RNAi, or ribozyme-based strategies (Parthasarathy et al. 1999, Backman et al. 2003). However, all nucleic acid-based therapeutics suffer from poor delivery.

\section{Combination therapies}

While targeted cancer monotherapy has demonstrated good efficacy when rationally designed, the combination of two or more agents may further improve the outcome, in an additive or synergistic manner, by causing a more profound anti-tumoral effect. More importantly, combination therapies have the potential of preventing drug resistance, which very often arises from the selection of pre-existing mutant subclones or from adaptive response to treatment (Gorre et al. 2001, Doebele et al. 2012, Straussman et al. 2012). A few preclinical studies have addressed the issue of combined treatment in MEN2 disease and/or thyroid neoplasia. Lopergolo and colleagues at the National Cancer Institute in Milan, Italy, showed that addition of cisplatin synergistically improved antitumor activity of sunitinib in MTC xenografts, by potentiating the activation of CD95-mediated apoptosis (Lopergolo et al. 2014). In another interesting study, sorafenib was shown to cause only transient MAPK pathway inhibition in MTC cell lines at low doses. This led the authors to test whether its effects could be enhanced by concomitant treatment with a MEK inhibitor. Indeed, combination with selumetinib (AZD6244, AstraZeneca) greatly increased growth inhibition compared to either single agent (Koh et al. 2012). While this combination has not yet been further investigated in thyroid cancer, the addition of MEK/ERK inhibitors to upstream kinase inhibitors (e.g., BRAF) has proven very successful in other tumors (Robert et al. 2015).

The concept of hitting driver oncogenic pathways at multiple nodes was explored by Jin and coworkers (Jin et al. 2011). The authors initially sought to block MEK/ERK and PI3K/AKT/mTOR pathways in DTCs driven by RAS, RAF or PTEN mutations. To this end, they combined the dual PI3K/mTOR inhibitor NVP-BEZ235 (Novartis) with the pan-RAF inhibitor RAF265/CHIR-265 (Novartis), which targets VEGFR2 as well. However, they noted that RAF265 is structurally related to sorafenib; hence, it may also block RET kinase. Indeed, the drug was shown to be a potent RET inhibitor and cooperated with BEZ235 to inhibit TT cells (carrying a RET C634W allele) growth in vivo. It is possible that VEGFR2 targeting contributed to in vivo tumor growth inhibition, similarly to all other effective RET inhibitors. More recently, another group explored synergistic inhibition of RET-mediated signaling and cell growth by the combination of RAF265 with a different PI3K inhibitor, named ZSTK474 (Bertazza et al. 2015). ERK and AKT activation, cell growth and survival, and calcitonin expression and secretion were all significantly better inhibited by the combination compared to single treatments, in TT cells.

Another possible strategy may involve the use of heat shock protein inhibitors. As mentioned earlier, pharmacological inhibition of HSP90 by 17-AAG or ganetespib downregulates RET levels in cells (Alfano et al. 2010, Lin et al. 2017) and sorafenib induces a similar effect after prolonged treatment (Plaza-Menacho et al. 2007). 
The combination of HSP90 and RET inhibitors may lead to improved block of oncogenic signaling in RETaddicted cells.

A few papers described the use of imatinib (Gleevec, STI-571, Novartis) against RET. However, the drug showed poor activity in preclinical and clinical studies (Cohen et al. 2002, de Groot et al. 2007). In one attempt to improve its efficacy in MTC models, authors combined imatinib with a FGFR4 inhibitor (PD173074, Ezzat et al. 2005). Although the drugs concentrations used in vitro were rather high, hardly achievable in vivo, the combination did obtain better inhibition of TT xenografts, at reasonable doses.

On the clinical side, a phase I/II trial of vandetanib plus the proteasome inhibitor bortezomib (Velcade, Millennium Pharmaceuticals) was run in adults with hereditary or sporadic, locally advanced or metastatic MTC. Phase I enrolled 21 patients to find the MTD. Analysis of tumor response in this group showed 29\% PR $(6 / 21)$, while only one patient was enrolled in the phase II and progressed (NCT00923247). A possibly interesting activity of semaxanib (SU5416) in combination with paclitaxel in two metastatic MTC patients remained anecdotal because the compound has then been discontinued. The trial was actually designed for headand-neck cancers, including thyroid neoplasm, and semaxanib was meant as an anti-angiogenic drug. Interestingly, the only two MTC patients enrolled were among the four patients (out of 11 evaluable) showing prolonged SD (Cooney et al. 2005). The documented anti-RET activity of the compound (Mologni et al. 2006) may explain these results. A recent single-arm phase 1 trial is currently recruiting patients with advanced cancers, to be treated with a combination of vandetanib plus everolimus, an mTOR inhibitor (NCT01582191). The idea is based on everolimus activity against $\mathrm{ABC}$ transporters, which limit drug efficacy, especially in the central nervous system. Indeed, a first successful case has been reported (Subbiah et al. 2015). Whether these results will be relevant to the MEN2/MTC population remains to be seen.

Finally, an innovative precision therapy trial (NCT02363647) is inviting patients with sporadic metastatic MTC. After next-generation genetic analysis to identify tumor drivers, a Drosophila model is rapidly generated and tested against a panel of FDA-approved drugs or drug combinations, to identify and propose a possible personalized treatment. Time will tell if this strategy will obtain superior response or cure rates compared to current approaches.

\section{Conclusions and future hope}

The discovery of RET mutations in MEN2 syndrome 25 years ago opened a new era for the management of the disease. After two decades of intense research, potent RET inhibitors have reached the clinical scene, with many more to come in the next few years (Mologni et al. $2017 a, b)$. As physicians know very well, to have a full array of drugs to treat cancer is a most desirable situation, when we are confronted with an enemy that changes rapidly to survive our attacks. However, it is currently unclear what are the mechanisms of primary or acquired resistance to RET inhibitors in thyroid cancer. This information is needed in order to rationally devise effective alternative targeted treatments, as demonstrated for CML patients (Redaelli et al. 2012). Surely, RET gatekeeper mutations cause a sharp decrease of efficacy for some drugs in vitro (e.g. vandetanib, Carlomagno et al. 2004). A recent work reported NRAS mutations in ponatinib-resistant RETrearranged NSCLC cells (Nelson-Taylor et al. 2017). It is also unknown whether sequential targeted therapies with multiple RET inhibitors will improve patients OS. Finally, all current drugs are anti-angiogenic compounds with limited selectivity for RET. Therefore, the relative contribution of anti-RET and anti-VEGFR activities in determining the clinical outcome is not known, although the ZETA trial indicated that RET-positive patients may respond better, suggesting a specific anticancer role for RET inhibition (Wells et al. 2012).

It has been an exciting time from the discovery of the target to the development of targeted treatments. Much remains to be done, but we (and Mary) can look forward with new optimism.

Declaration of interest

The authors declare that there is no conflict of interest that could be perceived as prejudicing the impartiality of this review.

\section{Funding}

This work did not receive any specific grant from any funding agency in the public, commercial or not-for-profit sector.

\section{References}

Abdel-Magid AF 2015 RET kinase inhibitors may treat cancer and gastrointestinal disorders. ACS Medicinal Chemistry Letters 6 13-14. (https://doi.org/10.1021/ml500402t)

Ahmed M, Barbachano Y, Riddell A, Hickey J, Newbold KL, Viros A, Harrington KJ, Marais R \& Nutting CM 2011 Analysis of the efficacy and toxicity of sorafenib in thyroid cancer: a phase II study in a UK 
based population. European Journal of Endocrinology $165315-322$ (https://doi.org/10.1530/EJE-11-0129)

Akeno-Stuart N, Croyle M, Knauf JA, Malaguarnera R, Vitagliano D, Santoro M, Stephan C, Grosios K, Wartmann M, Cozens R, et al. 2007 The RET kinase inhibitor NVP-AST487 blocks growth and calcitonin gene expression through distinct mechanisms in medullary thyroid cancer cells. Cancer Research 67 6956-6964. (https://doi.org/10.1158/0008-5472.CAN-06-4605)

Alfano L, Guida T, Provitera L, Vecchio G, Billaud M, Santoro M \& Carlomagno F 2010 RET is a heat shock protein 90 (HSP90) client protein and is knocked down upon HSP90 pharmacological block. Journal of Clinical Endocrinology and Metabolism 95 3552-3557. (https://doi.org/10.1210/jc.2009-2315)

Andreucci E, Francica P, Fearns A, Martin LA, Chiarugi P, Isacke CM \& Morandi A 2016 Targeting the receptor tyrosine kinase RET in combination with aromatase inhibitors in ER positive breast cancer xenografts. Oncotarget 7 80543-80553. (https://doi.org/10.18632/ oncotarget.11826)

Andrews SW, Blake JF, Chicarelli MJ, Golos A, Haas J, Jiang Y \& Kolakowski GR 2017 Substituted Pyrazolo[1,5-a]Pyridine Compounds as Ret Kinase Inhibitors. Array Biopharma, Inc., WO2017011776.

Angiolini M, Buffa L, Menichincheri M, Motto I, Polucci P, Traquandi G \& Zuccotto F 2014 Pyrrolo[2,3-d]Pyrimidine Derivatives, Process for their Preparation and their Use as Kinase Inhibitors. Nerviano Medical Sciences, WO2014184069.

Arai T, Taniyama Y \& Kokubo T 2007 Preventives/Remedies for Cancer. Takeda Pharmaceutical Company Limited, WO2007049624.

Ardini E, Banfi P, Avanzi N, Ciomei M, Polucci P, Cirla A, Ermoli A, Motto I, Casale E, Canevari G, et al. 2017 NMS-E668, a potent and selective RET kinase inhibitor characterized by specificity towards VEGFR2 and high antitumor efficacy against RET-driven models. In Proceedings of the American Association for Cancer Research Annual Meeting 2017; Washington, DC. Cancer Research 201777 (Supplement 13) abstract 2082. (https://doi.org/10.1158/1538-7445. AM2017-2082)

Atallah V, Hocquelet A, Do Cao C, Zerdoud S, De La Fouchardiere C, Bardet S, Italiano A, Dierick-Galet A, Leduc N, Bonichon F, et al. 2016 Activity and safety of sunitinib in patients with advanced radioiodine refractory thyroid carcinoma: a retrospective analysis of 57 patients. Thyroid 26 1085-1092. (https://doi.org/10.1089/ thy.2015.0648)

Backman C, Zhang Y, Hoffer BJ \& Tomac AC 2003 Short interfering RNAs (siRNAs) for reducing dopaminergic phenotypic markers. Journal of Neuroscience Methods 131 51-56. (https://doi.org/10.1016/ S0165-0270(03)00236-X)

Bajpai M 2009 Fostamatinib, a Syk inhibitor prodrug for the treatment of inflammatory diseases. IDrugs 12 174-185.

Bentzien F, Zuzow M, Heald N, Gibson A, Shi Y, Goon L, Yu P, Engst S, Zhang W, Huang D, et al. 2013 In vitro and in vivo activity of cabozantinib (XL184), an inhibitor of RET, MET, and VEGFR2, in a model of medullary thyroid cancer. Thyroid 23 1569-1577. (https://doi.org/10.1089/thy.2013.0137)

Bertazza L, Barollo S, Radu CM, Cavedon E, Simioni P, Faggian D, Plebani M, Pelizzo MR, Rubin B, Boscaro M, et al. 2015 Synergistic antitumour activity of RAF265 and ZSTK474 on human TT medullary thyroid cancer cells. Journal of Cellular and Molecular Medicine 19 2244-2252. (https://doi.org/10.1111/jcmm.12612)

Bible KC, Suman VJ, Molina JR, Smallridge RC, Maples WJ, Menefee ME, Rubin J, Sideras K, Morris JC 3rd, McIver B, et al. 2010 Efficacy of pazopanib in progressive, radioiodine-refractory, metastatic differentiated thyroid cancers: results of a phase 2 consortium study. Lancet Oncology 11 962-972. (https://doi.org/10.1016/S14702045(10)70203-5)

Bible KC, Suman VJ, Molina JR, Smallridge RC, Maples WJ, Menefee ME, Rubin J, Karlin N, Sideras K, Morris JC 3rd, et al. 2014 A multicenter phase 2 trial of pazopanib in metastatic and progressive medullary thyroid carcinoma: MC057H. Journal of Clinical Endocrinology and Metabolism 99 1687-1693. (https://doi.org/10.1210/jc.2013-3713)

Bikas A, Kundra P, Desale S, Mete M, O'Keefe K, Clark BG, Wray L, Gandhi R, Barett C, Jelinek JS, et al. 2016 Phase 2 clinical trial of sunitinib as adjunctive treatment in patients with advanced differentiated thyroid cancer. European Journal of Endocrinology 174 373-380. (https://doi.org/10.1530/EJE-15-0930)

Bocciardi R, Mograbi B, Pasini B, Borrello MG, Pierotti MA, Bourget I, Fischer S, Romeo G \& Rossi B 1997 The multiple endocrine neoplasia type $2 \mathrm{~B}$ point mutation switches the specificity of the Ret tyrosine kinase towards cellular substrates that are susceptible to interact with Crk and Nck. Oncogene 15 2257-2265. (https://doi. org/10.1038/sj.onc.1201413)

Borrello MG, Ardini E, Locati LD, Greco A, Licitra L \& Pierotti MA 2013 RET inhibition: implications in cancer therapy. Expert Opinion on Therapeutic Targets 17 403-419. (https://doi.org/10.1517/14728222.2 013.758715)

Brandhuber B, Haas J, Tuch B, Ebata K, Bouhana K, McFaddin E, Williams L, Winski S, Brown E, Burkhard M, et al. 2016 The development of LOXO-292, a potent, KDR/VEGFR2-sparing RET kinase inhibitor for treating patients with RET-dependent cancers. In EORTC-NCI-AACR Molecular Targets and Cancer Therapeutics Symposium. (available at: https://ir.loxooncology.com/docs/ presentations/2016_EORTC_LOXO-292_POSTER.pdf)

Brose MS, Nutting CM, Jarzab B, Elisei R, Siena S, Bastholt L, de la Fouchardiere C, Pacini F, Paschke R, Shong YK, et al. 2014 Sorafenib in radioactive iodine-refractory, locally advanced or metastatic differentiated thyroid cancer: a randomised, double-blind, phase 3 trial. Lancet 384 319-328. (https://doi.org/10.1016/S01406736(14)60421-9)

Bruheim S, Kristian A, Uenaka T, Suo Z, Tsuruoka A, Nesland JM \& Fodstad Ø 2011 Antitumour activity of oral E7080, a novel inhibitor of multiple tyrosine kinases, in human sarcoma xenografts. International Journal of Cancer 129 742-750. (https://doi.org/10.1002/ ijc.25922)

Capdevila J, Carrato A, Tabernero J \& Grande E 2014 What could Nintedanib (BIBF 1120), a triple inhibitor of VEGFR, PDGFR, and FGFR, add to the current treatment options for patients with metastatic colorectal cancer? Critical Reviews in Oncology/Hematology 92 83-106. (https://doi.org/10.1016/j.critrevonc.2014.05.004)

Carlomagno F, Vitagliano D, Guida T, Ciardiello F, Tortora G, Vecchio G, Ryan AJ, Fontanini G, Fusco A \& Santoro M 2002 ZD6474, an orally available inhibitor of KDR tyrosine kinase activity, efficiently blocks oncogenic RET kinases. Cancer Research 62 7284-7290.

Carlomagno F, Guida T, Anaganti S, Vecchio G, Fusco A, Ryan AJ, Billaud M \& Santoro M 2004 Disease associated mutations at valine 804 in the RET receptor tyrosine kinase confer resistance to selective kinase inhibitors. Oncogene 23 6056-6063. (https://doi.org/10.1038/ sj.onc.1207810)

Carr LL, Mankoff DA, Goulart BH, Eaton KD, Capell PT, Kell EM, Bauman JE \& Martins RG 2010 Phase II study of daily sunitinib in FDG-PET-positive, iodine-refractory differentiated thyroid cancer and metastatic medullary carcinoma of the thyroid with functional imaging correlation. Clinical Cancer Research 16 5260-5268. (https://doi.org/10.1158/1078-0432.CCR-10-0994)

Cheung M, Demartino MP, Eidam HS, Guan AH, Qin D, Wu C, Gong Z, Yang H, Yu H \& Zhang Z 2016 Novel Compounds as Rearranged during Transfection (ret) Inhibitors. GlaxoSmithKline, WO2016037578.

Chow LQ \& Eckhardt SG 2007 Sunitinib: from rational design to clinical efficacy. Journal of Clinical Oncology 25 884-896. (https://doi. org/10.1200/JCO.2006.06.3602)

Chu TF, Rupnick MA, Kerkela R, Dallabrida SM, Zurakowski D, Nguyen L, Woulfe K, Pravda E, Cassiola F, Desai J, et al. 2007 Cardiotoxicity associated with tyrosine kinase inhibitor sunitinib. Lancet 370 2011-2019. (https://doi.org/10.1016/S01406736(07)61865-0)
2018 Society for Endocrinology Published by Bioscientifica Ltd. Printed in Great Britain 
Clemens GR, Schroeder RE, Magness SH, Weaver EV, Lech JW, Taylor VC, Masuda ES, Baluom M \& Grossbard EB 2009 Developmental toxicity associated with receptor tyrosine kinase Ret inhibition in reproductive toxicity testing. Birth Defects Research Part A: Clinical and Molecular Teratology 85 130-136. (https://doi. org/10.1002/bdra.20505)

Cohen MS, Hussain HB \& Moley JF 2002 Inhibition of medullary thyroid carcinoma cell proliferation and RET phosphorylation by tyrosine kinase inhibitors. Surgery 132 960-966; discussion 966-967. (https://doi.org/10.1067/msy.2002.128562)

Cooney MM, Tserng KY, Makar V, McPeak RJ, Ingalls ST, Dowlati A, Overmoyer B, McCrae K, Ksenich P, Lavertu P, et al. 2005 A phase IB clinical and pharmacokinetic study of the angiogenesis inhibitor SU5416 and paclitaxel in recurrent or metastatic carcinoma of the head and neck. Cancer Chemotherapy and Pharmacology 55 295-300. (https://doi.org/10.1007/s00280-004-0871-5)

Cortes JE, Kantarjian H, Shah NP, Bixby D, Mauro MJ, Flinn I, O’Hare T, Hu S, Narasimhan NI, Rivera VM, et al. 2012 Ponatinib in refractory Philadelphia chromosome-positive leukemias. New England Journal of Medicine 367 2075-2088. (https://doi.org/10.1056/NEJMoa1205127)

Coxon A, Bready J, Kaufman S, Estrada J, Osgood T, Canon J, Wang L, Radinsky R, Kendall R, Hughes P, et al. 2012 Anti-tumor activity of motesanib in a medullary thyroid cancer model. Journal of Endocrinological Investigation 35 181-190. (https://doi. org/10.3275/7609)

Dar AC, Das TK, Shokat KM \& Cagan RL 2012 Chemical genetic discovery of targets and anti-targets for cancer polypharmacology. Nature 486 80-84. (https://doi.org/10.1038/nature11127)

Dawson SJ, Conus NM, Toner GC, Raleigh JM, Hicks RJ, McArthur G \& Rischin D 2008 Sustained clinical responses to tyrosine kinase inhibitor sunitinib in thyroid carcinoma. Anticancer Drugs 19 547-552. (https://doi.org/10.1097/CAD.0b013e3282fc6cf7)

De Falco V, Buonocore P, Muthu M, Torregrossa L, Basolo F, Billaud M, Gozgit JM, Carlomagno F \& Santoro M 2013 Ponatinib (AP24534) is a novel potent inhibitor of oncogenic RET mutants associated with thyroid cancer. Journal of Clinical Endocrinology and Metabolism $\mathbf{9 8}$ E811-E819. (https://doi.org/10.1210/jc.2012-2672)

de Groot JW, Zonnenberg BA, van Ufford-Mannesse PQ, de Vries MM, Links TP, Lips CJ \& Voest EE 2007 A phase II trial of imatinib therapy for metastatic medullary thyroid carcinoma. Journal of Clinical Endocrinology and Metabolism 92 3466-3469. (https://doi. org/10.1210/jc.2007-0649)

Doebele RC, Pilling AB, Aisner D, Kutateladze TG, Le AT, Weickhardt AJ Kondo KL, Linderman DJ, Heasley LE, Franklin WA, et al. 2012 Mechanisms of resistance to crizotinib in patients with ALK gene rearranged non-small cell lung cancer. Clinical Cancer Research 18 1472-1482. (https://doi.org/10.1158/1078-0432.CCR-11-2906)

Dunna NR, Kandula V, Girdhar A, Pudutha A, Hussain T, Bandaru S \& Nayarisseri A 2015 High affinity pharmacological profiling of dual inhibitors targeting RET and VEGFR2 in inhibition of kinase and angiogeneis events in medullary thyroid carcinoma. Asian Pacific Journal of Cancer Prevention 16 7089-7095. (https://doi.org/10.7314/ APJCP.2015.16.16.7089)

Edery P, Eng C, Munnich A \& Lyonnet S 1997 RET in human development and oncogenesis. Bioessays 19 389-395. (https://doi. org/10.1002/bies.950190506)

Eidam HS, Demartino MP, Gong Z, Guan AH, Raha K, Wu C, Yang H, Yu H, Zhang Z \& Cheung M 2014 Pyridine Derivatives as Rearranged during Transfection (ret) Kinase Inhibitors. GlaxoSmithKline, WO2014141187.

Elisei R, Schlumberger MJ, Müller SP, Schöffski P, Brose MS, Shah MH, Licitra L, Jarzab B, Medvedev V \& Kreissl MC 2012 Cabozantinib in progressive medullary thyroid cancer. Journal of Clinical Oncology 31 3639-3646. (https://doi.org/10.1200/JCO.2012.48.4659)

Encinas M, Crowder RJ, Milbrandt J \& Johnson EM Jr 2004 Tyrosine 981, a novel ret autophosphorylation site, binds c-Src to mediate neuronal survival. Journal of Biological Chemistry 279 18262-18269, Epub 12004 Feb 18206. (https://doi.org/10.1074/jbc.M400505200)

Ezzat S, Huang P, Dackiw A \& Asa SL 2005 Dual inhibition of RET and FGFR4 restrains medullary thyroid cancer cell growth. Clinical Cancer Research 11 1336-1341.

Ferreira R, Nilsson JR, Solano C, Andreasson J \& Grotli M 2015 Design, synthesis and inhibitory activity of photoswitchable RET kinase inhibitors. Scientific Reports 5 9769. (https://doi.org/10.1038/ srep09769)

Fleming PE, Brooijmans N, Dipietro LV, Kim JL, Wenglowsky SM \& Zhang Y 2016 2-(Pyridin-3-yl)-Pyrimidine Derivatives as RET Inhibitors. Blueprint Medicines Corporation, WO2016127074.

Fox E, Widemann BC, Chuk MK, Marcus L, Aikin A, Whitcomb PO, Merino MJ, Lodish M, Dombi E, Steinberg SM, et al. 2013 Vandetanib in children and adolescents with multiple endocrine neoplasia type 2B associated medullary thyroid carcinoma. Clinical Cancer Research 19 4239-4248. (https://doi.org/10.1158/1078-0432. CCR-13-0071)

Frett B, Carlomagno F, Moccia ML, Brescia A, Federico G, De Falco V, Admire B, Chen Z, Qi W, Santoro M, et al. 2015 Fragment-based discovery of a dual pan-RET/VEGFR2 kinase inhibitor optimized for single-agent polypharmacology. Angewandte Chemie International Edition in English 54 8717-8721. (https://doi.org/10.1002/ anie.201501104)

Gadgeel SM, Gandhi L, Riely GJ, Chiappori AA, West HL, Azada MC, Morcos PN, Lee RM, Garcia L, Yu L, et al. 2014 Safety and activity of alectinib against systemic disease and brain metastases in patients with crizotinib-resistant ALK-rearranged non-small-cell lung cancer (AF-002JG): results from the dose-finding portion of a phase $1 / 2$ study. Lancet Oncology 15 1119-1128. (https://doi.org/10.1016/S14702045(14)70362-6)

Gautschi O, Milia J, Filleron T, Wolf J, Carbone DP, Owen D, Camidge R, Narayanan V, Doebele RC, Besse B, et al. 2017 Targeting RET in patients with RET-rearranged lung cancers: results from the global, multicenter RET registry. Journal of Clinical Oncology 35 1403-1410. (https://doi.org/10.1200/JCO.2016.70.9352)

Gild ML, Landa I, Ryder M, Ghossein RA, Knauf JA \& Fagin JA 2013 Targeting mTOR in RET mutant medullary and differentiated thyroid cancer cells. Endocrine-Related Cancer 20 659-667. (https://doi. org/10.1530/ERC-13-0085)

Goldberg K, Hamilton N, Jones S, Jordan A, Lyons A, Newton R, Ogilvie D \& Waszkowycz B 2015 Quinazoline Compounds. Cancer Research Technology, WO2015079251.

Goodman VL, Rock EP, Dagher R, Ramchandani RP, Abraham S, Gobburu JV, Booth BP, Verbois SL, Morse DE, Liang CY, et al. 2007 Approval summary: sunitinib for the treatment of imatinib refractory or intolerant gastrointestinal stromal tumors and advanced renal cell carcinoma. Clinical Cancer Research $\mathbf{1 3}$ 1367-1373. (https://doi.org/10.1158/1078-0432.CCR-06-2328)

Goodman KM, Kjaer S, Beuron F, Knowles PP, Nawrotek A, Burns EM, Purkiss AG, George R, Santoro M, Morris EP, et al. 2014 RET recognition of GDNF-GFRalpha1 ligand by a composite binding site promotes membrane-proximal self-association. Cell Reports $\mathbf{8}$ 1894-1904. (https://doi.org/10.1016/j.celrep.2014.08.040)

Gorre ME, Mohammed M, Ellwood K, Hsu N, Paquette R, Rao PN \& Sawyers CL 2001 Clinical resistance to STI-571 cancer therapy caused by BCR-ABL gene mutation or amplification. Science 293 876-880, Epub 2001 Jun 2021. (https://doi.org/10.1126/science.1062538)

Grieco M, Santoro M, Berlingieri MT, Melillo RM, Donghi R, Bongarzone I, Pierotti MA, Della Porta G, Fusco A \& Vecchio G 1990 PTC is a novel rearranged form of the ret proto-oncogene and is frequently detected in vivo in human thyroid papillary carcinomas. Cell 60 557-563. (https://doi.org/10.1016/00928674(90)90659-3)

Han M, Li S, Ai J, Sheng R, Hu Y \& Geng M 2016 Discovery of 4-chloro3-(5-(pyridin-3-yl)-1,2,4-oxadiazole-3-yl)benzamides as novel RET
(2) 2018 Society for Endocrinology Published by Bioscientifica Ltd. Printed in Great Britain 
kinase inhibitors. Bioorganic and Medicinal Chemistry Letters 26 5679-5684. (https://doi.org/10.1016/j.bmcl.2016.10.061)

Ito S, Iwashita T, Asai N, Murakami H, Iwata Y, Sobue G \& Takahashi M 1997 Biological properties of Ret with cysteine mutations correlate with multiple endocrine neoplasia type $2 \mathrm{~A}$, familial medullary thyroid carcinoma, and Hirschsprung's disease phenotype. Cancer Research 57 2870-2872.

Iwashita T, Asai N, Murakami H, Matsuyama M \& Takahashi M 1996 Identification of tyrosine residues that are essential for transforming activity of the ret proto-oncogene with MEN2A or MEN2B mutation. Oncogene 12 481-487.

Iwashita T, Kato M, Murakami H, Asai N, Ishiguro Y, Ito S, Iwata Y, Kawai K, Asai M, Kurokawa K, et al. 1999 Biological and biochemical properties of Ret with kinase domain mutations identified in multiple endocrine neoplasia type $2 \mathrm{~B}$ and familial medullary thyroid carcinoma. Oncogene 18 3919-3922. (https://doi.org/10.1038/sj. onc.1202742)

James J, Ruggeri B, Armstrong RC, Rowbottom MW, Jones-Bolin S, Gunawardane RN, Dobrzanski P, Gardner MF, Zhao H, Cramer MD, et al. 2012 CEP-32496: a novel orally active BRAF(V600E) inhibitor with selective cellular and in vivo antitumor activity. Molecular Cancer Therapeutics 11 930-941. (https://doi.org/10.1158/1535-7163. MCT-11-0645)

Jeong WJ, Mo JH, Park MW, Choi IJ, An SY, Jeon EH \& Ahn SH 2011 Sunitinib inhibits papillary thyroid carcinoma with RET/PTC rearrangement but not BRAF mutation. Cancer Biology and Therapy 12 458-465. (https://doi.org/10.4161/cbt.12.5.16303)

Jin N, Jiang T, Rosen DM, Nelkin BD \& Ball DW 2011 Synergistic action of a RAF inhibitor and a dual PI3K/mTOR inhibitor in thyroid cancer. Clinical Cancer Research 17 6482-6489. (https://doi. org/10.1158/1078-0432.CCR-11-0933)

Jordan AM, Begum H, Fairweather E, Fritzl S, Goldberg K, Hopkins GV, Hamilton NM, Lyons AJ, March HN, Newton R, et al. 2016 Anilinoquinazoline inhibitors of the RET kinase domain-Elaboration of the 7-position. Bioorganic and Medicinal Chemistry Letters 26 2724-2729. (https://doi.org/10.1016/j.bmcl.2016.03.100)

Kantarjian H, Sawyers C, Hochhaus A, Guilhot F, Schiffer C, Gambacorti-Passerini C, Niederwieser D, Resta D, Capdeville R, Zoellner U, et al. 2002 Hematologic and cytogenetic responses to imatinib mesylate in chronic myelogenous leukemia. New England Journal of Medicine 346 645-652. (https://doi.org/10.1056/ NEJMoa011573)

Kato M, Takeda K, Kawamoto Y, Iwashita T, Akhand AA, Senga T, Yamamoto M, Sobue G, Hamaguchi M, Takahashi M, et al. 2002 Repair by Src kinase of function-impaired RET with multiple endocrine neoplasia type $2 \mathrm{~A}$ mutation with substitutions of tyrosines in the COOH-terminal kinase domain for phenylalanine. Cancer Research 62 2414-2422.

Kim DW, Jo YS, Jung HS, Chung HK, Song JH, Park KC, Park SH Hwang JH, Rha SY, Kweon GR, et al. 2006 An orally administered multitarget tyrosine kinase inhibitor, SU11248, is a novel potent inhibitor of thyroid oncogenic RET/papillary thyroid cancer kinases. Journal of Clinical Endocrinology and Metabolism 91 4070-4076, Epub 2006 Jul 4018. (https://doi.org/10.1210/jc.2005-2845)

Kodama T, Tsukaguchi T, Satoh Y, Yoshida M, Watanabe Y, Kondoh O \& Sakamoto H 2014 Alectinib shows potent antitumor activity against RET-rearranged non-small cell lung cancer. Molecular Cancer Therapeutics 13 2910-2918. (https://doi.org/10.1158/1535-7163.MCT14-0274)

Koh YW, Shah MH, Agarwal K, McCarty SK, Koo BS, Brendel VJ, Wang C, Porter K, Jarjoura D, Saji M, et al. 2012 Sorafenib and Mek inhibition is synergistic in medullary thyroid carcinoma in vitro. Endocrine-Related Cancer 19 29-38. (https://doi.org/10.1530/ERC-110155)

Kumarasamy VM \& Sun D 2017 Demonstration of a potent RET transcriptional inhibitor for the treatment of medullary thyroid carcinoma based on an ellipticine derivative. International Journal of Oncology 51 145-157. (https://doi.org/10.3892/ijo.2017.3994)

Kurzrock R, Sherman SI, Ball DW, Forastiere AA, Cohen RB, Mehra R, Pfister DG, Cohen EEW, Janisch L \& Nauling F 2010 Activity of XL184 (cabozantinib), an oral tyrosine kinase inhibitor, in patients with medullary thyroid cancer. Journal of Clinical Oncology 29 2660-2666. (https://doi.org/10.1200/JCO.2010.32.4145)

Lam ET, Ringel MD, Kloos RT, Prior TW, Knopp MV, Liang J, Sammet S, Hall NC, Wakely PE Jr, Vasko VV, et al. 2010 Phase II clinical trial of sorafenib in metastatic medullary thyroid cancer. Journal of Clinical Oncology 28 2323-2330. (https://doi.org/10.1200/JCO.2009.25.0068)

Li J, Qin S, Xu J, Xiong J, Wu C, Bai Y, Liu W, Tong J, Liu Y, Xu R, et al. 2016 Randomized, double-blind, placebo-controlled phase III trial of apatinib in patients with chemotherapy-refractory advanced or metastatic adenocarcinoma of the stomach or gastroesophageal junction. Journal of Clinical Oncology 34 1448-1454. (https://doi. org/10.1200/JCO.2015.63.5995)

Li GG, Somwar R, Joseph J, Smith RS, Hayashi T, Martin L, Franovic A, Schairer A, Martin E, Riely GJ, et al. 2017 Antitumor activity of RXDX-105 in multiple cancer types with RET rearrangements or mutations. Clinical Cancer Research 23 2981-2990. (https://doi. org/10.1158/1078-0432.CCR-16-1887)

Lin C, Wang S, Xie W, Zheng R, Gan Y \& Chang J 2016a Apatinib inhibits cellular invasion and migration by fusion kinase KIF5B-RET via suppressing RET/Src signaling pathway. Oncotarget 7 59236-59244. (https://doi.org/10.18632/oncotarget.10985)

Lin JJ, Kennedy E, Sequist LV, Brastianos PK, Goodwin KE, Stevens S, Wanat AC, Stober LL, Digumarthy SR, Engelman JA, et al. $2016 b$ Clinical activity of alectinib in advanced RET-rearranged non-small cell lung cancer. Journal of Thoracic Oncology 11 2027-2032. (https://doi.org/10.1016/j.jtho.2016.08.126)

Lin SF, Lin JD, Hsueh C, Chou TC, Yeh CN, Chen MH \& Wong RJ 2017 Efficacy of an HSP90 inhibitor, ganetespib, in preclinical thyroid cancer models. Oncotarget 8 41294-41304. (https://doi.org/10.18632/ oncotarget.17180)

Liu X, Vega QC, Decker RA, Pandey A, Worby CA \& Dixon JE 1996 Oncogenic RET receptors display different autophosphorylation sites and substrate binding specificities. Journal of Biological Chemistry 271 5309-5312. (https://doi.org/10.1074/jbc.271.10.5309)

Lopergolo A, Nicolini V, Favini E, Dal Bo L, Tortoreto M, Cominetti D, Folini M, Perego P, Castiglioni V, Scanziani E, et al. 2014 Synergistic cooperation between sunitinib and cisplatin promotes apoptotic cell death in human medullary thyroid cancer. Journal of Clinical Endocrinology and Metabolism 99 498-509. (https://doi.org/10.1210/ jc.2013-2574)

Marx SJ 2005 Molecular genetics of multiple endocrine neoplasia types 1 and 2. Nature Reviews Cancer 5 367-375. (https://doi.org/10.1038/ nrc1610)

Matsui J, Yamamoto Y, Funahashi Y, Tsuruoka A, Watanabe T, Wakabayashi T, Uenaka T \& Asada M 2008 E7080, a novel inhibitor that targets multiple kinases, has potent antitumor activities against stem cell factor producing human small cell lung cancer H146, based on angiogenesis inhibition. International Journal of Cancer 122 664-671. (https://doi.org/10.1002/ijc.23131)

Menichincheri M, Angiolini M, Bertrand JA, Caruso M, Polucci P, Quartieri F, Salom B, Salsa M \& Zuccotto F 2014 Substituted Pyrimidinyl and Pyridinyl-Pyrrolopyridinones, Process for their Preparation and their Use as Kinase Inhibitors. Nerviano Medical Sciences, WO2014072220.

Moccia M, Liu Q, Guida T, Federico G, Brescia A, Zhao Z, Choi HG, Deng X, Tan L, Wang J, et al. 2015 Identification of novel small molecule inhibitors of oncogenic RET kinase. PLOS ONE 10 e0128364. (https://doi.org/10.1371/journal.pone.0128364)

Mologni L 2011 Development of RET kinase inhibitors for targeted cancer therapy. Current Medicinal Chemistry 18 162-175. (https://doi. org/10.2174/092986711794088308) (c) 2018 Society for Endocrinology Published by Bioscientifica Ltd. Printed in Great Britain 
Mologni L, Sala E, Cazzaniga S, Rostagno R, Kuoni T, Puttini M, Bain J, Cleris L, Redaelli S, Riva B, et al. 2006 Inhibition of RET tyrosine kinase by SU5416. Journal of Molecular Endocrinology 37 199-212. (https://doi.org/10.1677/jme.1.01999)

Mologni L, Redaelli S, Morandi A, Plaza-Menacho I \& GambacortiPasserini C 2013 Ponatinib is a potent inhibitor of wild-type and drug-resistant gatekeeper mutant RET kinase. Molecular and Cellular Endocrinology 377 1-6. (https://doi.org/10.1016/j.mce.2013.06.025)

Mologni L, Dalla Via M, Chilin A, Palumbo M \& Marzaro G $2017 a$ Discovery of wt RET and V804M RET inhibitors: from hit to lead. ChemMedChem 12 1390-1398. (https://doi.org/10.1002/ cmdc.201700243)

Mologni L, Gambacorti-Passerini C, Goekjian P \& Scapozza L 2017b RET kinase inhibitors: a review of recent patents (2012-2015). Expert Opinion on Therapeutic Patents 27 91-99. (https://doi.org/10.1080/135 43776.2017.1238073)

Mulligan LM, Kwok JB, Healey CS, Elsdon MJ, Eng C, Gardner E, Love DR, Mole SE, Moore JK, Papi L, et al. 1993 Germ-line mutations of the RET proto-oncogene in multiple endocrine neoplasia type $2 \mathrm{~A}$. Nature 363 458-460. (https://doi.org/10.1038/363458a0)

Murakami H, Iwashita T, Asai N, Shimono Y, Iwata Y, Kawai K \& Takahashi M 1999 Enhanced phosphatidylinositol 3-kinase activity and high phosphorylation state of its downstream signalling molecules mediated by ret with the MEN 2B mutation. Biochemical and Biophysical Research Communications 262 68-75. (https://doi. org/10.1006/bbrc.1999.1186)

Murakami H, Yamamura Y, Shimono Y, Kawai K, Kurokawa K \& Takahashi M 2002 Role of Dok1 in cell signaling mediated by RET tyrosine kinase. Journal of Biological Chemistry 277 32781-32790. (https://doi.org/10.1074/jbc.M202336200)

Nair A, Lemery SJ, Yang J, Marathe A, Zhao L, Zhao H, Jiang X, He K, Ladouceur G, Mitra AK, et al. 2015 FDA approval summary: lenvatinib for progressive, radio-iodine-refractory differentiated thyroid cancer. Clinical Cancer Research 21 5205-5208. (https://doi. org/10.1158/1078-0432.CCR-15-1377)

Nelson-Taylor SK, Le AT, Yoo M, Schubert L, Mishall KM, Doak A, Varella-Garcia M, Tan AC \& Doebele RC 2017 Resistance to RETinhibition in RET-rearranged NSCLC is mediated by reactivation of RAS/MAPK signaling. Molecular Cancer Therapeutics 16 1623-1633. (https://doi.org/10.1158/1535-7163.MCT-17-0008)

Newton R, Bowler KA, Burns EM, Chapman PJ, Fairweather EE, Fritzl SJR, Goldberg KM, Hamilton NM, Holt SV, Hopkins GV, et al. 2016 The discovery of 2-substituted phenol quinazolines as potent RET kinase inhibitors with improved KDR selectivity. European Journal of Medicinal Chemistry 112 20-32. (https://doi.org/10.1016/j. ejmech.2016.01.039)

Park SR, Speranza G, Piekarz R, Wright JJ, Kinders RJ, Wang L, Pfister T, Trepel JB, Lee MJ, Alarcon S, et al. 2013 A multi-histology trial of fostamatinib in patients with advanced colorectal, non-small cell lung, head and neck, thyroid, and renal cell carcinomas, and pheochromocytomas. Cancer Chemotherapy and Pharmacology $\mathbf{7 1}$ 981-990. (https://doi.org/10.1007/s00280-013-2091-3)

Parthasarathy R, Cote GJ \& Gagel RF 1999 Hammerhead ribozymemediated inactivation of mutant RET in medullary thyroid carcinoma. Cancer Research 59 3911-3914.

Patel MR, Fakih M, Olszanski AJ, Lockhart AC, Drilon AE, Fu S, Bazhenova L, Patel R, Oliver JW, Multani PS, et al. 2016 A phase 1 dose escalation study of RXDX-105, an oral RET and BRAF inhibitor, in patients with advanced solid tumors. Journal of Clinical Oncology 34 (15 Suppl) 2574. (https://doi.org/10.1200/JCO.2016.34.15_ suppl.2574)

Phay JE \& Shah MH 2010 Targeting RET receptor tyrosine kinase activation in cancer. Clinical Cancer Research 16 5936-5941. (https://doi.org/10.1158/1078-0432.CCR-09-0786)

Pinilla-Ibarz J, Cortes J, Kim D-W, Le Coutre P, Paquette R, Chuah C, Nicolini FE, Apperley JF, Khoury HJ, Dipersio JF, et al. 2013 Clinical impact of dose modification on response to ponatinib in patients with chronic phase chronic myeloid leukemia. In ASH Annual Meeting Abstracts. Blood 122 4007. (available at: http://www. bloodjournal.org/content/122/21/4007)

Plaza-Menacho I, Barnouin K, Goodman K, Martinez-Torres RJ, Borg A, Murray-Rust J, Mouilleron S, Knowles P \& McDonald NQ 2014 Oncogenic RET kinase domain mutations perturb the autophosphorylation trajectory by enhancing substrate presentation in trans. Molecular Cell 53 738-751. (https://doi.org/10.1016/j. molcel.2014.01.015)

Plaza-Menacho I, Burzynski GM, de Groot JW, Eggen BJ \& Hofstra RM 2006 Current concepts in RET-related genetics, signaling and therapeutics. Trends in Genetics 22 627-636. (https://doi. org/10.1016/j.tig.2006.09.005)

Plaza-Menacho I, Mologni L, Sala E, Gambacorti-Passerini C, Magee AI, Links TP, Hofstra RM, Barford D \& Isacke CM 2007 Sorafenib functions to potently suppress RET tyrosine kinase activity by direct enzymatic inhibition and promoting RET lysosomal degradation independent of proteasomal targeting. Journal of Biological Chemistry 282 29230-29240. (https://doi.org/10.1074/jbc.M703461200)

Plaza-Menacho I, Morandi A, Mologni L, Boender P, GambacortiPasserini C, Magee AI, Hofstra RM, Knowles P, McDonald NQ \& Isacke CM 2011 Focal adhesion kinase (FAK) binds RET kinase via its FERM domain, priming a direct and reciprocal RET-FAK transactivation mechanism. Journal of Biological Chemistry 286 17292-17302. (https://doi.org/10.1074/jbc.M110.168500)

Plaza Menacho I, Koster R, van der Sloot AM, Quax WJ, Osinga J, van der Sluis T, Hollema H, Burzynski GM, Gimm O, Buys CH, et al. 2005 RET-familial medullary thyroid carcinoma mutants Y791F and S891A activate a Src/JAK/STAT3 pathway, independent of glial cell line-derived neurotrophic factor. Cancer Research 65 1729-1737. (https://doi.org/10.1158/0008-5472.CAN-04-2363)

Polverino A, Coxon A, Starnes C, Diaz Z, DeMelfi T, Wang L, Bready J, Estrada J, Cattley R, Kaufman S, et al. 2006 AMG 706, an oral, multikinase inhibitor that selectively targets vascular endothelial growth factor, platelet-derived growth factor, and kit receptors, potently inhibits angiogenesis and induces regression in tumor xenografts. Cancer Research 66 8715-8721. (https://doi. org/10.1158/0008-5472.CAN-05-4665)

Quintas-Cardama A \& Cortes J 2008 Therapeutic options against BCRABL1 T315I-positive chronic myelogenous leukemia. Clinical Cancer Research 14 4392-4399. (https://doi.org/10.1158/1078-0432.CCR-080117)

Quintela-Fandino M, Bueno MJ, Lombardia L, Gil M, GonzalezMartin A, Marquez R, Bratos R, Guerra J, Tan E, Lopez A, et al. 2014 Selective activity over a constitutively active RET-variant of the oral multikinase inhibitor dovitinib: results of the CNIO-BR002 phase I-trial. Molecular Oncology 8 1719-1728. (https://doi.org/10.1016/j. molonc.2014.07.005)

Raghav KP \& Blumenschein GR 2011 Motesanib and advanced NSCLC: experiences and expectations. Expert Opinion on Investigational Drugs 20 859-869. (https://doi.org/10.1517/13543784.2011.579103)

Rahal R, Evans EK, Hu W, Maynard M, Fleming P, DiPietro L, Kim JL, Sheets MP, Wilson DP, Wilson KJ, et al. 2016 The development of potent, selective RET inhibitors that target both wild-type RET and prospectively identified resistance mutations to multi-kinase inhibitors. In American Association for Cancer Research Annual Meeting; New Orleans, LA. Cancer Research 76 (Supplement 14) abstract 2641. (https://doi.org/10.1158/1538-7445.AM2016-2641)

Rahal R, Maynard M, Hu W, Brubaker JD, Cao Q, Kim JL, Sheets MP, Wilson DP, Fleming P, Wilson KJ, et al. 2017 OP91: BLU-667 is a potent and highly selective RET inhibitor in development for RET-driven thyroid cancers. Boston, MA, USA: World Congress on Thyroid Cancer. (available at: http://thyroidworldcongress.com/presentation/ op91-blu-667-is-a-potent-and-highly-selective-ret-inhibitor-indevelopment-for-ret-driven-thyroid-cancers/)
(2) 2018 Society for Endocrinology Published by Bioscientifica Ltd. Printed in Great Britain 
Ravaud A, de la Fouchardiere C, Caron P, Doussau A, Do Cao C, Asselineau J, Rodien P, Pouessel D, Nicolli-Sire P, Klein M, et al. 2017 A multicenter phase II study of sunitinib in patients with locally advanced or metastatic differentiated, anaplastic or medullary thyroid carcinomas: mature data from the THYSU study. European Journal of Cancer 76 110-117. (https://doi.org/10.1016/j. ejca.2017.01.029)

Redaelli S, Mologni L, Rostagno R, Piazza R, Magistroni V, Ceccon M, Viltadi M, Flynn D \& Gambacorti-Passerini C 2012 Three novel patient-derived BCR/ABL mutants show different sensitivity to second and third generation tyrosine kinase inhibitors. American Journal of Hematology 87 E125-E128. (https://doi.org/10.1002/ ajh.23338)

Robert C, Karaszewska B, Schachter J, Rutkowski P, Mackiewicz A, Stroiakovski D, Lichinitser M, Dummer R, Grange F, Mortier L, et al. 2015 Improved overall survival in melanoma with combined dabrafenib and trametinib. New England Journal of Medicine 372 30-39. (https://doi.org/10.1056/NEJMoa1412690)

Robinson BG, Paz-Ares L, Krebs A, Vasselli J \& Haddad R 2010 Vandetanib $(100 \mathrm{mg})$ in patients with locally advanced or metastatic hereditary medullary thyroid cancer. Journal of Clinical Endocrinology and Metabolism 95 2664-2671. (https://doi.org/10.1210/jc.2009-2461)

Robledo M, Gil L, Pollan M, Cebrian A, Ruiz S, Azanedo M, Benitez J, Menarguez J \& Rojas JM 2003 Polymorphisms G691S/S904S of RET as genetic modifiers of MEN 2A. Cancer Research 63 1814-1817.

Salvatore D, Melillo RM, Monaco C, Visconti R, Fenzi G, Vecchio G, Fusco A \& Santoro M 2001 Increased in vivo phosphorylation of ret tyrosine 1062 is a potential pathogenetic mechanism of multiple endocrine neoplasia type 2B. Cancer Research 61 1426-1431.

Santoro M, Rosati R, Grieco M, Berlingieri MT, D'Amato GL, de Franciscis V \& Fusco A 1990 The ret proto-oncogene is consistently expressed in human pheochromocytomas and thyroid medullary carcinomas. Oncogene 5 1595-1598.

Santoro M, Carlomagno F, Romano A, Bottaro DP, Dathan NA, Grieco M, Fusco A, Vecchio G, Matoskova B, Kraus MH, et al. 1995 Activation of RET as a dominant transforming gene by germline mutations of MEN2A and MEN2B. Science 267 381-383. (https://doi. org/10.1126/science.7824936)

Schimke RN 1984 Genetic aspects of multiple endocrine neoplasia. Annual Review of Medicine 35 25-31. (https://doi.org/10.1146/ annurev.me.35.020184.000325)

Schlumberger MJ, Elisei R, Bastholt L, Wirth LJ, Martins RG, Locati LD, Jarzab B, Pacini F, Daumerie C, Droz J-P, et al. 2009 Phase II study of safety and efficacy of motesanib in patients with progressive or symptomatic, advanced or metastatic medullary thyroid cancer. Journal of Clinical Oncology 23 3794-3801. (https://doi.org/10.1200/ JCO.2008.18.7815)

Schlumberger M, Jarzab B, Cabanillas ME, Robinson B, Pacini F, Ball DW, McCaffrey J, Newbold K, Allison R, Martins RG, et al. 2016 A phase II trial of the multitargeted tyrosine kinase inhibitor lenvatinib (E7080) in advanced medullary thyroid cancer. Clinical Cancer Research 22 44-53. (https://doi.org/10.1158/1078-0432.CCR15-1127)

Schuringa JJ, Wojtachnio K, Hagens W, Vellenga E, Buys CH, Hofstra R \& Kruijer W 2001 MEN2A-RET-induced cellular transformation by activation of STAT3. Oncogene 20 5350-5358. (https://doi. org/10.1038/sj.onc.1204715)

Scott AJ, Messersmith WA \& Jimeno A 2015 Apatinib: a promising oral antiangiogenic agent in the treatment of multiple solid tumors. Drugs of Today $\mathbf{5 1}$ 223-229. (https://doi.org/10.1358/ dot.2015.51.4.2320599)

Sherman SI, Wirth LJ, Droz JP, Hofmann M, Bastholt L, Martins RG, Licitra L, Eschenberg MJ, Sun YN, Juan T, et al. 2008 Motesanib diphosphate in progressive differentiated thyroid cancer. New England Journal of Medicine 359 31-42. (https://doi.org/10.1056/ NEJMoa075853)
Song Z, Xia Z, Ji Y, Xing L, Gao Y, Ai J, Geng M \& Zhang A 2016 An orally available tyrosine kinase ALK and RET dual inhibitor bearing the tetracyclic benzo[b]carbazolone core. European Journal of Medicinal Chemistry 118 244-249. (https://doi.org/10.1016/j. ejmech.2016.04.046)

Sonpavde G \& Hutson TE 2007 Pazopanib: a novel multitargeted tyrosine kinase inhibitor. Current Oncology Reports 9 115-119. (https://doi.org/10.1007/s11912-007-0007-2)

Straussman R, Morikawa T, Shee K, Barzily-Rokni M, Qian ZR, Du J, Davis A, Mongare MM, Gould J, Frederick DT, et al. 2012 Tumour micro-environment elicits innate resistance to RAF inhibitors through HGF secretion. Nature $\mathbf{4 8 7}$ 500-504. (https://doi. org/10.1038/nature11183)

Subbiah V, Berry J, Roxas M, Guha-Thakurta N, Subbiah IM, Ali SM, McMahon C, Miller V, Cascone T, Pai S, et al. 2015 Systemic and CNS activity of the RET inhibitor vandetanib combined with the mTOR inhibitor everolimus in KIF5B-RET re-arranged non-small cell lung cancer with brain metastases. Lung Cancer 89 76-79. (https://doi.org/10.1016/j.lungcan.2015.04.004)

Sun L, Tran N, Tang F, App H, Hirth P, McMahon G \& Tang C 1998 Synthesis and biological evaluations of 3-substituted indolin-2-ones: a novel class of tyrosine kinase inhibitors that exhibit selectivity toward particular receptor tyrosine kinases. Journal of Medicinal Chemistry 41 2588-2603. (https://doi.org/10.1021/jm980123i)

Sun L, Tran N, Liang C, Tang F, Rice A, Schreck R, Waltz K, Shawver LK, McMahon G \& Tang C 1999 Design, synthesis, and evaluations of substituted 3-[(3- or 4-carboxyethylpyrrol-2-yl)methylidenyl]indolin2-ones as inhibitors of VEGF, FGF, and PDGF receptor tyrosine kinases. Journal of Medicinal Chemistry 42 5120-5130. (https://doi. org/10.1021/jm9904295)

Sun L, Tran N, Liang C, Hubbard S, Tang F, Lipson K, Schreck R, Zhou Y, McMahon G \& Tang C 2000 Identification of substituted 3-[(4,5,6,7-tetrahydro-1H-indol-2-yl)methylene]-1,3-dihydroindol-2ones as growth factor receptor inhibitors for VEGF-R2 (Flk-1/KDR), FGF-R1, and PDGF-Rbeta tyrosine kinases. Journal of Medicinal Chemistry 43 2655-2663. (https://doi.org/10.1021/jm9906116)

Takahashi M, Iwashita T, Santoro M, Lyonnet S, Lenoir GM \& Billaud M 1999 Co-segregation of MEN2 and Hirschsprung's disease: the same mutation of RET with both gain and loss-of-function? Human Mutation 13 331-336. (https://doi.org/10.1002/(SICI)10981004(1999)13:4<331::AID-HUMU11>3.0.CO;2-\#)

Vidal M, Wells S, Ryan A \& Cagan R 2005 ZD6474 suppresses oncogenic RET isoforms in a Drosophila model for type 2 multiple endocrine neoplasia syndromes and papillary thyroid carcinoma. Cancer Research 65 3538-3541. (https://doi.org/10.1158/0008-5472.CAN-044561)

Wang C, Liu H, Song Z, Ji Y, Xing L, Peng X, Wang X, Ai J, Geng M \& Zhang A 2017 Synthesis and structure-activity relationship study of pyrazolo[3,4-d]pyrimidines as tyrosine kinase RET inhibitors. Bioorganic and Medicinal Chemistry Letters 27 2544-2548. (https://doi. org/10.1016/j.bmcl.2017.03.088)

Wedge SR, Ogilvie DJ, Dukes M, Kendrew J, Chester R, Jackson JA, Boffey SJ, Valentine PJ, Curwen JO, Musgrove HL, et al. 2002 ZD6474 inhibits vascular endothelial growth factor signaling, angiogenesis, and tumor growth following oral administration. Cancer Research 62 4645-4655.

Wells SA Jr, Gosnell JE, Gagel RF, Moley J, Pfister D, Sosa JA, Skinner M, Krebs A, Vasselli J \& Schlumberger M 2010 Vandetanib for the treatment of patients with locally advanced or metastatic hereditary medullary thyroid cancer. Journal of Clinical Oncology 28 767-772. (https://doi.org/10.1200/JCO.2009.23.6604)

Wells SA Jr, Robinson BG, Gagel RF, Dralle H, Fagin JA, Santoro M, Baudin E, Elisei R, Jarzab B, Vasselli JR, et al. 2012 Vandetanib in patients with locally advanced or metastatic medullary thyroid cancer: a randomized, double-blind phase III trial. Journal of Clinical Oncology 30 134-141. (https://doi.org/10.1200/JCO.2011.35.5040)
(2) 2018 Society for Endocrinology Published by Bioscientifica Ltd. Printed in Great Britain 
Wells SA Jr, Pacini F, Robinson BG \& Santoro M 2013 Multiple endocrine neoplasia type 2 and familial medullary thyroid carcinoma: an update. Journal of Clinical Endocrinology and Metabolism 98 3149-3164. (https://doi.org/10.1210/jc.2013-1204)

Wiegering A, Korb D, Thalheimer A, Kammerer U, Allmanritter J, Matthes N, Linnebacher M, Schlegel N, Klein I, Ergun S, et al. 2014 E7080 (lenvatinib), a multi-targeted tyrosine kinase inhibitor, demonstrates antitumor activities against colorectal cancer xenografts. Neoplasia 16 972-981. (https://doi.org/10.1016/j.neo.2014.09.008)

Wu H, Shih JY \& Yang JC 2015 Rapid response to sunitinib in a patient with lung adenocarcinoma harboring KIF5B-RET fusion gene. Journal of Thoracic Oncology 10 e95-e96. (https://doi.org/10.1097/ JTO.0000000000000611)

Yakes FM, Chen J, Tan J, Yamaguchi K, Shi Y, Yu P, Qian F, Chu F, Bentzien F, Cancilla B, et al. 2011 Cabozantinib (XL184), a novel MET and VEGFR2 inhibitor, simultaneously suppresses metastasis, angiogenesis, and tumor growth. Molecular Cancer Therapeutics 10 2298-2308. (https://doi.org/10.1158/1535-7163.MCT-11-0264)

Yoon H, Kwak Y, Choi S, Cho H, Kim ND \& Sim T 2016 A

pyrazolo[3,4-d]pyrimidin-4-amine derivative containing an isoxazole moiety is a selective and potent inhibitor of RET gatekeeper mutants. Journal of Medicinal Chemistry 59 358-373. (https://doi. org/10.1021/acs.jmedchem.5b01522)

Yoon H, Shin I, Nam Y, Kim ND, Lee KB \& Sim T 2017 Identification of a novel 5-amino-3-(5-cyclopropylisoxazol-3-yl)-1-isopropyl-1Hpyrazole-4-carboxamide as a specific RET kinase inhibitor. European Journal of Medicinal Chemistry 125 1145-1155. (https://doi. org/10.1016/j.ejmech.2016.10.050)

Yuan ZL, Guan YJ, Wang L, Wei W, Kane AB \& Chin YE 2004 Central role of the threonine residue within the $\mathrm{p}+1$ loop of receptor tyrosine kinase in STAT3 constitutive phosphorylation in metastatic cancer cells. Molecular and Cellular Biology 24 9390-9400. (https://doi.org/10.1128/МСВ.24.21.93909400.2004)

Zhou T, Commodore L, Huang WS, Wang Y, Thomas M, Keats J, Xu Q, Rivera VM, Shakespeare WC, Clackson T, et al. 2011 Structural mechanism of the Pan-BCR-ABL inhibitor ponatinib (AP24534): lessons for overcoming kinase inhibitor resistance. Chemical Biology and Drug Design 77 1-11. (https://doi. org/10.1111/j.1747-0285.2010.01054.x)

Received in final form 7 November 2017 Accepted 14 November 2017
(C) 2018 Society for Endocrinology Published by Bioscientifica Ltd. Printed in Great Britain 